\title{
Analisis Keterampilan Siswa Madrasah Ibtidaiyah dalam Menulis Puisi Anak Berdasarkan Teori Nurgiantoro
}

\author{
Idammatussilmi, ${ }^{*}$ Anifatul Latifah \\ Sekolah Tinggi Agama Islam Nahdlatul Ulama Temanggung \\ *Penulis korespondensi: idammatussilmi96@gmail.com
}

DOI : https://doi.org/10.21580/jieed.v1i2.8258

Received: 2021-10-10, Revised: 2021-11-06,

Accepted: 2021-11-02, Published: 2021-11-06

\begin{abstract}
Abstrak
Penelitian ini bertujuan untuk menganalisis desain pembelajaran menulis puisi anak melalui pembelajaran daring selama pandemi Covid-19. Penelitian ini menggunakan pendekatan deskriptif kualitatif dengan jumlah subjek 20. Metode pengumpulan data yaitu wawancara, observasi dan dokumentasi. Data penelitian diuji keabsahannnya dengan triangulasi sumber. Teknik analisis data yang digunakan terdiri dari tahap reduksi data, penyajian data, dan penarikan kesimpulan. Hasil penelitian ini menunjukan bahwa puisi anak yang buat oleh siswa Madrasah Ibtidaiyah Ma'arif Asmaul Husna sudah sesuai dengan unsur intrinsik teori Nurgiantoro.
\end{abstract}

Kata Kunci: pembelajaran daring, keterampilan menulis puis, pembelajaran puisi

\section{Analysis of the Skills of Madrasah Ibtidaiyah Students in Writing Children's Poems Based on Nurgiantoro's Theory}

\begin{abstract}
This study aims to analyze the design of learning to write poetry for children through online learning during the Covid-19 pandemic. This study used a qualitative descriptive approach with 20 subjects. The data collection methods were interviews, observation and documentation. The validity of the research data was tested by triangulation of sources. The data analysis technique used consisted of data reduction, data presentation, and conclusion drawing. The results of this study indicate that the children's poetry made by students of Madrasah Ibtidaiyah Ma'arif Asmaul Husna is in accordance with the intrinsic elements of Nurgiantoro's theory.
\end{abstract}

Keywords: online learning, poetry writing skills, poetry learning 


\section{PENDAHULUAN}

Pembalajaran daring telah dilaksanakan di Madrasah Ibtidaiyah untuk mencegah penyebaran virus Covid-19. DI sisi lain, banyak orang tua dan siswa yang mengeluh karena kebosanan selama pelaksanaan pembelajaran dari rumah. Salah satu cara guru untuk menciptakan siswa yang produktif adalah dengan melibatkan bantuan orang tua untuk melatih dan membiasakan siswa membuat suatu karya. Salah satu cara yang dapat perbengaruh dalam meningkatkan keproduktifan siswa adalah dengan pembiasaan.

Strategi yang diterapkan sekolah dalam meningkatkan produktifitas siswa sangat beragam. Apalagi sekolah sudah menerapkan pembelajaran secara daring, guru sudah terbiasa dalam menilai bebarapa tugas yang bevariasi. Oleh karena itu dalam meningkatkan produktifitas siswa di masa pandemi guru dapat melakukan pembiasaan baru yang dapat megurangi kebosanan siswa dengan pembiasaan berkarya.

Masalah yang sering dihadapi di dalam dunia pendidikan kita adalah masalah lemahnya dukungan siswa dalam mengembangkan kemampuan mencipkatan sebuah karya. Otak anak dipaksa untuk mengingat dan menimbun berbagai informasi tanpa dituntut untuk memahami informasi yang diingatnya untuk menghubungakan dengan kehidupan sehai-hari (Sanjaya, 2016, p. 2). Oleh Karena itu, pendidikan sangat diarahkan untuk membuat siswa aktif dalam proses kegiatan belajar mengajar dengan berbagai macam cara yang ditempuh salah satunya dengan cara menggunakan strategi-strategi pembelajaran sehingga siswa tidak bosan dan pasif ketika proses pelaksanaan pembelajaran daring.

Kurikulum 2013 ini pelajaran dirubah dengan berbasis teks meskipun dalam penerapan menggunakan empat keterampilan berbahasa (Mulyanto, 2013, p. 6). Keterampilan bahasa Indonesia meliputi empat jenis keterampilan yaitu, menyimak, berbicara, membaca, dan menulis (Tarigan, 2008, p. 2). Menulis merupakan salah satu keterampilan berbahasa yang sangat penting karena membutuhkan serangkaian proses berpikir. Hal ini disebabkan karena menulis selain kegiatan menyampaikan pesan dalam wujud tulisan juga kemampuan dalam merangkai suatu kata-kata yang disusun membentuk sebuah paragraf. Selain itu, keterampilan menulis merupakan syarat pintu masuk dalam berbagai macam kegiatan (Rosyidah et al., 2013, p. 26).

Puisi merupakan suatu karya sasta yang membutuhkan satu perenungan, ide, pikiran dan perasaan melalui sebuah karangan baik fiksi maupun non fiksi (Zainudin, 2015, p. 16). Puisi anak adalah puisi yang dibuat untuk anak-anak, baik oleh anak sendiri maupun orang dewasa (Wahyuni \& Harun, 2018). Puisi anak juga didefinisikan sebagai puisi yang menjelaskan tentang anak dan menggunakan anak sebagai objek dalam membuat puisi (Naelofaria \& Siregar, 2021). 
Puisi anak memiliki karakteristik yang sangat identik teradap karakteristik sastra anak yaitu pengungkapan sesuatu dari kacamata anak (Nurgiyantoro, 2016, p. 314). Tema-tema puisi anak antara lain adalah masalah keluarga, persahabatan, liburan, rumah, dan tempat-tempat lain yang menyentuh dalam kehidupan anak (Mursini, 2010). Puisi pada anak hadir karena dibaca ataupun disuarakan oleh anakanak. Misalnya, anak dapat manangakap pembiacaraan dari lingkungan kemudian anak menunjukanya dalam sebuah puisi. Kalaupun anak itu sudah bisa menbaca puisi akan hadir dari tulisan yang dibaca.

Menurut Nurgiantoro, puisi anak harus memiliki unsur intrinsik, yaitu: (1) bunyi yang meliputi rima dan irama, (2) kata, (3) sarana retorika dan tema. Rima merupakan pengulangan bunyi dalam puisi untuk mencapai keindahan. Bunyi ini didayagunakan melalui bntuk perulangan bunyi sehingga puisi dapat lebih indah dan menarik. Aspek bunyi melakat pada kata ada bunyi tiruan yang bukan merupakan kata (Nurgiyantoro, 2016).

Manfaat menulis secara umum adalah: 1) Ide dan pemikiran seseorang akan lebih awet, menyebar luas, dan dapat dipelajari lagi jika dituangkan ke dalam bentuk tulisan, 2) melegakanpikiran, jiwa dari kepenatan, kesumpekan, dan stress, 3) meningkatkan rasa percaya diri seseorang, 4) menambah daya saing dan penghasilan (Budiastuti dkk, 2014). Adapun manfaat menulis puisi bagi siswa adalah agar siswa dapat mengekspresikan pikirannya melalui bahasa yang indah, dapat melatih kepekaan siswa dalam berimajinasi, dan dapat menambah pengetahuan dan wawasan siswa tentang kehidupan di sekitarnya (Nur \& Mannahali, 2021).

Berdasarkan uraian mengenai hakikat menulis dan puisi yang telah dijabarkan sebelumnya, dapat disimpulkan bahwa menulis puisi adalah rangkaian kegiatan produktif dan ekspresif yang dilakukan seseorang untuk mengungkapkan gagasannya dalam bentuk puisi yang di dalamnya mengandung keindahan sehingga pembaca dapat mengerti maksud dan ungkapan hati penyairnya. Oleh karena itu, penelitian ini akan menganalisis kemampuan siswa Madrasah Ibtidaiyah dalam menulis puisi berdasarkan teori Nurgiyantoro.

\section{METODE}

Penelitian ini merupakan penelitian deskriptif kualitatif. Penelitian kualitatif merupakan suatu pendekatan dalam melakukan riset yang yang berorientasi pada fenomena gejala yang bersifat alami (Sugiyono, 2019, p. 2)(Hidayati, 2017, p. 2). Pendekatan kualitatif sebagai prosedur penelitian yang menghasilkan data deskriptif berupa kata-kata tertulis atau lisan dari orang-orang dan perilaku yang dapat diamati (Moleong, 2011, p. 4).

Teknik pengumpulan data pada penelitian kualitatif adalah menggunakan teknik pengumpulan data sevara gabungan. Analisis data bersifat induktif 
berdasarkan fakta-fakta yang ditemukan di lapangan. Hasil dari fakta-fakta yang ditemukan dilapangan kemudian dikonstruksikan menjadi hipotesis. Metode kualitatif dimulai dengan menggunakan kerangka penafsiran yang mempengaruhi studi yang terkait dengan makna yang dikenakan oleh individu atau kelompok pada suatu permasalahan sosial atau manusia (Batubara, 2017).

Pada penelitian ini, peneliti menggunakan data-data yang terkait dengan peningkatan keterampilan menulis puisi anak berbasis daring di MI ma'arif Asmaul Husna Kranggan. Subyek penelitian dipilih menggunakan purpose sampling dan snowball sampling. Metode pengumpulan data menggunakan observasi, wawancara, dan dokumentasi. Penulis melakukan wawancara secara daring dan luring. Untuk wawancara kepada wali murid peneliti melakukanya secara daring untuk memutuskan penyebaran virus. Pengambilan dokumentasi selama kegiatan daring peneliti menggunakan komunikasi lewat whastapp group.

Peneliti menggunakan teknik triangulasi untuk memeriksa keabsahan data. Dalam penggunanan teknik triangulasi ini, peneliti memeriksa, meneliti dan membandingkan dengan sumber dan metode, yang dapat dilakukan dengan mengajukan berbagai macam pertanyaan, dan mengecek berbagai metode agra pengecekan kepercayaan data dapat dilakukan.

Analisis data yang digunakan peneliti yaitu metode analisis data menggunakan teknik deskriptif yang dikembangkan oleh Miles and Huberman. teknik ini mengemukakan bahwa aktifitas dalam analisis data kualitatif dilakukan secara interaktif dan berlangsung secara terus menerus sampai tuntas, sehingga datanya sudah jenuh. Aktifitas dalam analisis data yaitu reduksi data, penyajian data, dan penarikan kesimpulan (Sugiyono, 2019).

\section{HASIL}

Hasil penelitian ini menunjukan bahwa anak-anak kurang begitu aktif selama proses pembelajaran daring karena pekerjaan yang seharusnya dikerjakan oleh anak malah dikerjakn oleh orang tuanya. Hal tersebut menjadikan keaktifan dan tingkat berfikir siswa menurun. Masalah lain juga terjadi apabila anak sudah sering dipegangi gadjet siswa dengan mudah mengerjakan tugas yang diberikan guru dengan mencari di google, sehingga pembelajaran secara daring ini lebih menekankan pada penilaian karakter siswa dibandingkan dengan nilai pengetahuan. Dengan diadaakan program tabungan karya yang dilakuakan secara daring anak akan terbiasa dan meningkatkan keaktifan meskipun belajar di rumah tanpa dampingan dan bimbingan seorang guru secara langsung.

Menurut pendapat dari Ibu Indah Wahyu Ningsih selaku kepala madrasah MI Ma'arif Asmaul Husna menyatakan dalam meningkatkan keterampilan menulis puisi anak tentunya peran orang tua sangatlah penting. Oleh karena itu dalam meningkatkan keterampilan menulis puisi anak ini dilakukan dengan mengiriman 
karya dalam goolge form yang sudah disiapkan oleh peneliti. Google form yang digunakan siswa untuk mengiramkan karya diberinama "Tabungan Karya" dalam satu minggu siswa yang paling banyak mengirimkan karya akan mendapatkan nilai tambahan dan juga riwerd dari guru. Rewerd yang diberikan oleh guru akan membangun semanagt siswa dalam berkarya.

Peneliti dalam memberikan materi tentang menulis puisi anak merancang degan semenarik mungkin agar anak merespon dan tidak membosankan. Peneliti memberikan materi dengan menggabungkan beberapa gambar dan video. Serta memberikan tahapan-tahapan mudah cara membuat puisi anak. Penulis membarikan sedikit penjelas yang terkait dengan tahapan-tahan pembuatan puisi anak yang diberikan melalui whatapp group dengan berbentuk video setalah pemberian video peneliti memebuka tanya jawab kepada siswa mengenai penyampaian materi yang telah disampaikan. Dari sini siswa juga melakukan diskusi keluahan atau pendapat yang akan di sampaikan siswa. Peneliti memberikan meteri berupa video agar siswa dapat jelas, mudah untuk merespon dan memahaminya.

\section{PEMBAHASAN}

Puisi yang menarik merupakan puisi yang memiliki keindahan kata. Kualitas kata yang membangun dapat menuntukan bagus atau tidaknya sebuah puisi. Puisi anak tidak selamanya dibuat oleh anak, orang dewasapun bisa membuat puisi anak degan kemampuan berbahasa dan berekspresi sesuai dengan dunia anak. Puisi anak yang dibuat oleh anak-anakpun juga melakukan seleksi kata dengan memperhatikan keindahan dan makna agar mudah untuk dipahami dalam puisi yang akan disampaikan. Melihat hasil puisi anak yang dihasilkan siswa sudah mampu membuat memilih kata-kata untuk puisi yang dibuatnya dengan tepat. Kita lihat puisi di bawah ini.

\section{Balon Udara}

Bulat tubuhku

Api menjadi suber makananku

Menusuri cakrawala menjadi pekerjaanku

Menikmati indahnya dunia

Melintas jauh di udara

Bersahabat dengan langit birunya

Awan sebagai rambu-rambunya

Untuk mengurangi kecepatan lajunya

Menari bersama burung di udara

Berkenalan dengan alam semesta 
(Zidni Nuron, 11 tahun, MI Ma’arif Asmaul Husna)

Puisi di atas berbicara tentang ungkapan kekaguman akan balon udara ditulis oleh Zidni kelas 5 MI Ma'arif Asmaul Husna Temanggung. Siswa ini menyampaikan ciri-ciri balon udara dengan penghayalan anak saat naik balon udara. Itu semua di ungkapkan lewat puisi yang dirasakan dapat mewakili perasaannya. Aspek bunyi fokal yang didominasi oleh vocal /a/. /i/, /u/ dengan bunyi konsonan yang berfariasi dapat memeberikan suasana penuh riang dan nada penuh kekaguman. Peilihan kata yang digunakan juga sangat sederhana. Puisi itu sangat indah karena kepolosan yang sangat mencerminkan dunia anak.

Permajasan menjadi permainan makna dalam sebuah puisi. Permajasan merupakan bahasa kias atau pengungkapan kata yang bertujuan agar puisi lebih menarik dengan menggunakan makna konotasi dan denotasi yang secara langsung maupun tidak langsung makna yang ditunjuk. Dalam puisi anak permajasan masih sangat sederhana sesuia dengan karakteristik bahsa yang masih sangat sederhana baik dalam pemilihan kata maupun makna.

\section{B.J Habibi}

Kau pejuang Indonesia

Kau pahlawan Indonesia

Kau bunga bangsa

Kau mengharumkan nama bangsa di mata dunia

Pak Habibi ...

Pembuat pesawat pertama di Indonesia

Presiden ke 2 republik Indonesia

Apakah aku bisa sepertimu?

Kau sangat pandai

Pandai dalam bidang teknologi

Aku ingin seprtimu pak habibi

Menjadi putra kebanggaan Indonesia

Yang mengharumkan nama bangsa di mata dunia

(Muhammad Azzam Muhtaddin, 9 tahun, Mi ma'arif Asmaul Huna)

Bagi Azzam siswa kelas 4 MI ini, sosok BJ, Habibi merupakan sosok pahlawan bagai bunga yang dapat mengharumkan orang didekatnya. Satu-satunya pejuang yang dapat membuat pesawat sehingga bangsa Indonesia bisa terbawa dan mendapat nama di mata dunia. Polos dan sangat sederhana kata-kata yang digunakan. Azzam ini menggunakan majas alogori yang berupa ungkapan kiasan untuk mengungkapkan pikiranya.

Puisi anak tidak jauh dari dunia anak baik dalam pengungkapkan pengalamannya, dan sesuatu yang pernah ditemuinya. Tema-tema yang dipilih 
dalam puisi anak antara lain tentang keluarga, hobi, persahabatan, cita-cita , liburan dan lain-lain sesui dengan hal-hal yang ada di sekitar anak.

\section{Ibuku Pahlawanku}

Pahlawan tanpa gelar

Tanpa dibayar

Tanpa pengakuan

Ibu....ibu....

Kau selalu ada di sisiku

Kau selalu membantuku di saat aku kesusahan

Ibu suka menghiburku hingga aku tersenyumdan senang kembali

Disaat ibu lelah aku selalu membantumu

Saat aku sakit ibu pula yang merawatku

Oh ibuku...

Kau adalah pahlawanku

Mengasihku setiap waktu

Hingga uang saku setiap hariku

Beberapa mainan kau belikan untuk ku

Agar aku dapat bermain dengan teman-temanku

Membelikan baju , memberiku makan , memberikan segalanya

Dengan kasih sayang tak pernahkau tinggalkan

Aku sayang ibuku...

(Desi Nuraini, 12 Tahun, MI Ma'arif Asmaul Husna)

Puisi di atas menunjukan ungkapan kasih sayang kepada ibunya yang telah merawat, memberikan kasih sayang. Sosok ibu yang telah berjasa dan menjadi segalanya untuk anak untuk itu tema yang dibuat oleh Desi kelas 6 mengambil dari orang yang paling terdekatnya yaitu ibu.

Keteramplan menulis puisi anak merupakan salah satu keterampilan berbahasa yanga sangat penting. Memang menulis merupakan keterampilan yang terahir yang diterima siswa. Oleh karena itu menulis merupakan tahapan paling penting bagi kehidupan manusia, yaitu sebagai alat komunikasi. Keterampilan menulis puisi di sini peneliti akan menganalisi keterampilan menulis puisi anak yang memuat unsur-unsur puisi anak berdasarkan pendapat dari Nurgiantoro. 


\section{SIMPULAN}

Puisi anak yang ditulis oleh siswa Madrasah Ibtidaiyah Ma'arif Asmaul Husna Kranggan telah mengacu pada unsur instrinsik teori Nurgiantoro. Unsur puisi anak pertama yaitu bunyi yang meliputi rima da irama. Dalam Menentukan rima siswa sudah mampu mengekspresikan perasaan yang ingin di sampaikan aspek bunyi dan vocal dengan bunyi konsonan sudah berfariasi hal tersebut terlihat dari keikhlasan siswa dalam mengungkapkan. Unsur bunyi irama sudah terlihat dari urutan kata yang diungkapkan puisi.

Unsur puisi anak kedua yaitu kata, siswa sudah mampu menyeleksi kata dalam pembuatan puisi. Seleksi kata yang dilakukan siswa masih sangat sederhana yaitu melilih kata berdasarkan kacamata anank yang menunjukan kepolosan. Kepolosan inilah yang mendajikan keindahan tersendiri dari puisi anak.

Unsur bunyi ketiga, yaitu sarana retorika yaitu pemajasan. Majas sudah banyak digunakan siswa dalam pengungkapkan puisinya meskipun siswa masih menggunakan bahasa yang sederhana baik dalam pemilihan kata, dan pemaknaan. Unsur bunyi ke empat yaitu tema, pada bagian tema siswa sudah menuliskan berdasarkan pengalaman anak. Berdasarkan hasil puisi yang telah dibuat oleh siswa berbasis dalam jaringan sangat membantu siswa dalam meningkatkan keterampilan menulis puisi anak dalam mengisi waktu luang di masa pandemi.

\section{DAFTAR PUSTAKA}

Batubara. (2017). ParadigmaPenelitian Kualitatif dan Filsafat Ilmu Pengetahuan dalam Konseling,. Jurnal Fokus Konseling, 3, 67-78.

Budiastuti, W. dkk (2014). Peningkatan Motivasi Dan Keterampilan Menulis Puisi Dengan Penerapan Pendekatan Kontekstual Pada Siswa Sekolah Dasar. BASASTRA, 1(3).

Hidayati, P. N. (2017). Perilaku Hidup Bersih dan Sehat (PHBS) Sesuai Ajaran Islam Siswa Kelas V MI Maarif Dukuh. Elementary, 7.

Moleong, L. (2011). Metodologi Penelitian Kualitatif (Edisi Revisi). PT. Remaja Rosdakarya.

Mulyanto. (2013). Strategi Pembelajaran di Era Kurikulum 2013. Prestasi Pustaka.

Mursini, M. (2010). Ke Arah Bimbingan Apresiasi Puisi Anak-anak. Jurnal Bahas Unimed, (76), 74528.

Naelofaria, S., \& Siregar, I. (2021, September). Pemanfaatan Puisi Anak sebagai Media dalam Pengajaran BIPA. In Seminar Nasional SAGA\# 3 (Sastra, Pedagogik, dan Bahasa) (Vol. 3, No. 1, pp. 232-235).

Nur, M., Burhanuddin, B., \& Mannahali, M. (2021). Hubungan Antara Penguasaan Kosakata dengan Keterampilan Menulis Puisi Bahasa Jerman. Interference: Journal of Language, Literature, and Linguistics, 2(1), 64-70. 
Nurgiyantoro, B. (2016). Sastra Anak Pengantar Pemahaman Dunia Anak. Gadjah Mada University Press.

Rosyidah, R, S., \& Ermanto. (2013). Peningkatan Keterampilan Menulis Cerita Melalui Teknik Tiru Model Siswa Kelas III SD Padangsidimpuan. Jurnal Bahasa, Sastra Dan Pembelajaran, 1, 20-32.

Sanjaya, V. (2016). Strategi Pembelajaran Berorientasi Standar Proses Pendidikan. Penamedia Group.

Sugiyono. (2019). Metode Penelitian Pendidikan (Pendekatan Kualitantitatif, kualitatif, dan R\&D). Alfabeta.

Tarigan, H. G. (2008). Menulis Sebagai Keterampilan Berbahasa. Angkasa.

Wahyuni, S., \& Harun, M. (2018). Analisis struktur fisik dan struktur batin puisi anak dalam majalah potret anak cerdas. Master Bahasa, 6(2), 115-125.

Zainudin. (2015). Meningkatkan Kemampuan Menulis Puisi Bagi Siswa Kelas IV SDN 1 Dongko dengan Metode Praktek. Jurnal Kreatif Tadulako Online, 4 no.9, 35. 